\title{
Lifestyles in Postgraduate Students at the Universidad Santo Tomás - Colombia, a View from The Integral Formation
}

\author{
Sandra Posada-Bernal ${ }^{1 *}$, Darwin Arturo Muñoz Buitrago ${ }^{2}$ and Marlucio de \\ Souza Martins ${ }^{3}$ \\ ${ }^{1}$ Universidad Santo Tomás - Bogotá, Colombia \\ ${ }^{2}$ Universidad Santo Tomás - Bogotá, Colombia \\ ${ }^{3}$ Pontificia Universidad Javeriana - Bogotá, Colombia \\ *Corresponding author
}

\begin{abstract}
.
The objective of this investigation was identifying the lifestyles of the postgraduate students of the Universidad Santo Tomás - Colombia. For the WHO (2013), lifestyles are considered as a general form of human being's life centered in the interaction of life conditions and individual patterns of behavior. This research is a quantitative descriptive interpretative study. The sample was confirmed by 186 postgraduate students, of which $53 \%$ were men $(n=99)$ and $47 \%$ were women $(n=87)$, with age $35.5 \pm 14.5$ years and who studied the academic space of Humanism, Society and Ethics during the first semester of 2020. A self-administration questionnaire with 15 questions on the Likert Scale proposed by Nahas (2013) was used to evaluate nutritional factors, physical activity, preventive behavior, social relations, and stress control. The results showed a negative lifestyle index is evidenced by postgraduate students in the variables of nutritional factors, physical activity and preventive behavior, which are part of the individual behaviors involved in daily life; on the other hand, a positive lifestyle index is presented in the variables of social relations and stress control, where students feel satisfied with their friendships and try to set aside time to relax. It is necessary to offer spaces through the university welfare that offer to the postgraduate students, programs of promotion and prevention of the health; likewise, to promote the conscience of a healthy lifestyle within the classes that are offered in postgraduate courses, so that these have a direct incidence in the integral formation of the students.
\end{abstract}

Keywords: Lifestyles, Postgraduate Students, Integral Formation.

\section{Introduction}

There is a growing concern in the university environment about lifestyles and the consequences they may have on students' health. De Souza et al. (2015), state that lifestyles represent everyday actions that reflect people's attitudes and values, which are directly related to their quality of life. For Gómez-Acosta (2018), lifestyles are conceived as a set of behaviors that determine the health-disease process in combination with biological vulnerability, psycho-physiological reactivity, age, and gender. In this context, the universities are increasingly seeking more and better services for their academic community, worrying about identifying the type of student who will be part of their programs and for this purpose, plans are designed and executed 
for accompaniment, permanence and welfare that cover the needs that arise throughout their studies until completion. Much of the attention given by universities is focused on undergraduate students, given the time they will remain in the institution. But there are also postgraduate programs that are part of the institutional offer and for which there are also some spaces of their own, but given the time and organization of the pensum, many times it is difficult for this population to participate in everything that a university as an institution offers for their integral formation.

\subsection{Lifestyles}

In today's world, people are living a transformation by the era of globalization (Verano and Garavito, 2015). Therefore, to understand how people adapt to this change and overcome the challenges and problems that arise in everyday life, there is a need to consider the lifestyle that a person must organize their life. This concern about lifestyles arises from research given since the 20th century and the beginning of the 21 st century, which states that they are behavior schemes that understand habits and reflect in people's well-being. For this reason, lifestyles depend on the context in which the person is immersed, as well as on individual personal aspects in the area of decision making, and they can have an influence on a greater or lesser development of lifestyles, generating future health risks.

According to Suescún-Carrero et al. (2017), "the lifestyle construct is associated with ideas of individual behavior and patterns of conduct" (pp. 228). In this sense, lifestyle is related to the way a person lives and is involved in activities, routines and habits that consolidate a behavior. In turn, from this perspective, the social and family environment forms a set of values, norms, attitudes, habits, and behaviors that establish the lifestyle of the human being (Shelton, 2019).

In the same way, it should be mentioned that lifestyle is a human behavior that undergoes transformations from the biopsychosocial, which can develop changes in attitudes and behaviors to meet the needs within the personal development of the human being (WHO, 2013). In accordance with the above, during human development Cotrina and Rodriguez (2014) propose in its different stages "considering the variability and individuality of each person, they establish their own lifestyle, which is intimately related to health" (pp. 20). For the Centers for Disease Control and Prevention (2018), a healthy lifestyle is associated with the benefit for the improvement of the quality of life, which is composed of physical, mental and social well-being, through the perception of the human being, where the condition is linked to satisfy human needs (material, psychological, social and environmental).

According to Muchotrigo (2012), the healthy lifestyle "is considered a construct that involves a series of psychological, social, cultural and even economic factors that tend to maintain an adequate state of physical and mental health" (pp.75). In this sense, the idea of having a healthy lifestyle is framed by individual preventive behaviors such as not smoking, eating healthy foods, abstinence from alcohol and, also practicing physical activity on a regular basis. According to Diéz and López (2017), a healthy lifestyle is "related to the reduction of illness, stress and negative emotions, and also refers to a good diet and exercise regime, to cover our quota of sleep and to a correct distribution of time" (pp. 3). 
On the other hand, Nahas (2013), states that the lifestyle is understood as the set of habitual actions that reflect the attitudes, values and life opportunities of people, in addition, it is constituted by five factors mainly as: stress, nutrition, social relations, preventive behavior and physical activity. For De Souza Martins et al. (2017) and the American College of Sports Medicine - ACSM (2018), the growth of a negative lifestyle in society brings as a consequence the appearance of Chronic Non Communicable Diseases - NCDs, such as: high blood pressure, diabetes mellitus II and obesity. Among the most frequent NCDs are cardiovascular, cerebrovascular, cancer, diabetes and other metabolic disorders, respiratory and pulmonary diseases, osteomyoarticular disorders and kidney diseases (WHO, 2018; Grau, 2016).

Studies indicate that more than 57 million deaths in the world population were caused by NCDs, comprising mainly cardiovascular disease $(48 \%)$, cancer $(21 \%)$, chronic respiratory disease (12\%), and diabetes (3.5\%) (WHO, 2013; Arestedt et al., 2014). According to Krupp and Chatton (2014), tobacco consumption is the leading cause of death in Latin America, followed by physical inactivity, which accounts for $28 \%$ of NCDs-related deaths. Other studies conducted by Vidarte et al. (2012), determine that the level of sedentarism is $73 \%$ in the general Colombian population; by gender, the level of sedentarism in men is $61 \%$ and in women $84 \%$.

\subsection{Lifestyles and Postgraduate Students}

In Colombia many of the postgraduate programs offered by the various institutions of higher education have emerged from the dynamics of the disciplines themselves. This has given rise to an important diversity of interests that contribute to many of the institutional achievements, by giving a reflection on the whole being, the duty to be and the task of formation at this academic level. There are currently two types of advanced formation: continuing education or professional development and formal or academic education. The first is based on a system of learning and consolidation as an expression of creation. For these purposes, the Institutions of Higher Education - IES offer courses, workshops, diploma courses, seminars, conferences, and debates. The second requires a higher degree of learning, regulated at the national level (Decree 1330 of 2019) and focused on the creation or production of intellectual knowledge. In this group are the specializations, master's degrees and $\mathrm{PhD}$, which according to the National System of Information on Higher Education (SNIES), in Colombia are offered 8596 postgraduate programs (specializations, 6770; master's degrees, 1554, and doctorates 272 (Jaramillo, 2015).

Taking into account that there is not much literature available on the general characterization of postgraduate students, nor of their lifestyles, since most of the research focuses on the undergraduate level, the following is a presentation of some of the research found on studies with a postgraduate population. In the Colombian context, Sanabria et al. (2007), conducted research in the academic field mainly in health professionals attending postgraduate courses, where it was found that the population presented a healthy lifestyle, related to the practice of physical activity and sport. On the other hand, Arrivillaga et al. (2003) mentioned that postgraduate students around health presented an unhealthy lifestyle related to the consumption habit, from the high intake of sugary drinks, alcoholic beverages and cigarette consumption. In contrast, Valdez-Cuervo et al. (2013), conducted a study that aimed to define profiles of 146 
postgraduate students in science and engineering based on their perception of the importance and development of scientific skills. Likewise, Espinoza and Gonzalez (2014), sought to know what were the motives and reasons that a group of young persevering people expressed to continue their studies towards a $\mathrm{PhD}$ and their results show that different personal and social expectations have motivated them to consider as the best option to continue their studies towards postgraduate degree. Life planning, added to the motivation of the professors and the support of the family, augurs a stable and successful future, where studies play a very important role.

Finally, Espinoza and González (2014) show in their work the motivations and reasons of a group of young people who have obtained the best average of their undergraduate and postgraduate studies. In their results they present how their study practices have led them to establish new academic commitments. For these young people it is not an obstacle to devote themselves full-time to their postgraduate studies, but it is closely related to their work aspirations. This is an existing element, palpable and recognized by all participants in research, knowing that as postgraduate students they have great confidence in their academic skills, and are aware that they belong to a select group that has managed to access quality postgraduate degrees in the country or abroad. For them, continuing their education after the undergraduate program will place them with greater employment advantages than the rest of the young people who postgraduate with them. In this way and according to Muchotrigo (2012), there is a need to generate greater awareness and sensitivity in postgraduate students for the awareness of a healthy lifestyle as a fundamental factor in future quality of life.

\subsection{Postgraduate students at the Universidad Santo Tomas}

The University is therefore committed to a humanistic education for the university community to respond ethically, critically, and creatively to the problems of today's world. Thomistic Christian humanist thought centers its actions on the appreciation of the person as a human being, since this implies the development of three capacities: a. the capacity for self-examination, the propensity for self-reflective exercise, and the construction of critical thinking about the world of life; b. the capacity to see oneself as human in interdependence with others, implies the ethics of care for others and for the world; and c. the capacity to cultivate narrative imagination, implies the feeling of empathy, of putting oneself in the place of others in order to value the meaning of their feelings, desires, projects and achievements (Nusbaum, 2010).

Currently the University has within its offer of postgraduate courses $3 \mathrm{PhD}, 20$ masters and 16 specializations. In that sense, the purpose of this work was to identify the lifestyles of the postgraduate students at the Universidad Santo Tomás - Colombia, as part of their integral formation. The academic space Humanism, Society and Ethics assumes the purpose of humanistic formation proposed by the Department of Humanities and Integral Formation - DHIF which consists of two offer comprehension around the problems that affect the human being in the establishment of just, kind and co-responsible relationships so that from the philosophical horizon of the University, through professional practice, Thomistic can give critical, creative and ethical answers that allow them to overcome the growing inequality, the instrumentalization of bodies and nature in function of the generation of great economic capital, the crisis of democracy and the transcendental senses. 
This space has as a fundamental core problem: "the increasing inequality, the instrumentalization of the bodies and the nature, the crisis of the democracy and the transcendental senses demands the study of the problems that affect the human being in the establishment of their ethical relations so that the Thomistic generates processes of social and human transformation in their diverse contexts". Through the development of the academic space, the processes of teaching and learning are developed from the problematic question of the DHIF: in what way does the growing inequality, the instrumentalization of the bodies and nature, the crisis of democracy and of the transcendental senses demand the study of the problems that affect the human being in the establishment of their ethical relations so that the Thomistic generates processes of social and human transformation in their diverse contexts?

Using the academic space of Humanism, Society and Ethics to identify the lifestyles of postgraduate students is part of the criteria for pedagogical action as a proposal for a curricular definition for the DHIF; to this end, some basic concepts are established for their performance both within their work and in their projection at the local, regional and national levels (DHIF, 2015). These concepts are:

- The investigative character: it understands that research is inherent to the being and work of the university. From this we can see the need for a pedagogical practice that effectively carries out the formation of research skills, generating spaces that promote the formulation of anthropological, epistemological, socio-political and cultural problems that allow us to face local challenges in complex and global contexts.

- Interdisciplinarity and transdisciplinary: considering that the context of key problems is not resolved within the disciplines but in their effective articulation. The analyses and understandings require global and local views that allow disciplinary and professional knowledge and practices to be integrated into a project in time that reflects the past, present challenges, and future projections in an integrated view. This implies that contemporary knowledge must be increasingly relevant to the contexts and challenges of rebuilding the social fabric.

- Relevance: it is the configuration of the university as a space where personal, local, and global projects have a place and know how to respond to social, political and cultural demands of their environments.

In this sense, based on the panorama presented, it is important to broaden studies of lifestyle in the postgraduate field, emphasizing conceptual approaches in the current university context within the framework of human and integral formation through the class of Humanism, Society and Ethics.

\section{Methodology}

This research is a quantitative descriptive interpretive study to identify the lifestyles of postgraduate students at the Universidad Santo Tomas. This work was approached from a quantitative methodological perspective, since this type of methodology seeks to specify the particularities and important aspects of any phenomenon analyzed and to describe the trends of a group or population. It is also descriptive since it measures more independently the concepts and variables to show accurately the angles or dimensions of a phenomenon or situation (Hernández-Sampieri et al. 2018). The study population was composed of 186 postgraduate students, $53 \%$ of whom are men $(n=99)$ and $47 \%$ are women $(n=87)$, with age $35.5 \pm 14.5$ years, who were enrolled in the 
academic space of Humanism, Society and Ethics during the first semester of 2020. $74 \%$ of the students were pursuing a specialization $(n=138), 25 \%$ a master's degree $(\mathrm{n}=46)$ and $1 \% \mathrm{a} \mathrm{PhD}(\mathrm{n}=2)$. The students participating in the research were asked to sign an informed consent form that included the objectives of the study, the risk taken by participating in the research, the handling and confidentiality of the information, among other aspects. As a technique for data collection, content analysis was used, through a self-administration questionnaire proposed by Nahas (2013), which presents five categories of analysis with 15 Likert Scale questions: nutritional factors, physical activity, preventive behavior, social relations, and stress control.

\section{Results and discussion}

Based on the categories established by Nahas (2013) regarding lifestyles, the most relevant results for each of them are presented below.

\subsection{Nutritional factors}

For postgraduate students in terms of daily food intake, 59\% $(n=110)$ report that they do not include at least 5 servings of fruits and vegetables and $41 \%(n=76)$ do; also $51 \%(n=95)$ do not avoid eating high-fat foods, fried foods, and sweets and 49\% ( $n=91)$ do avoid them, also $31 \%(n=57)$ do not consume 4 to 5 servings of food a day including breakfast but $69 \%(n=129)$ do. These results reflect that a part of the postgraduate population, in terms of the nutritional factors, present negative indices that can compromise their health in the long term. It is also evident that the greatest negative behavior is centered in men while women present more favorable behaviors in some habits. The following figure presents the disaggregated data.

Figure 1: Nutritional factors of lifestyles

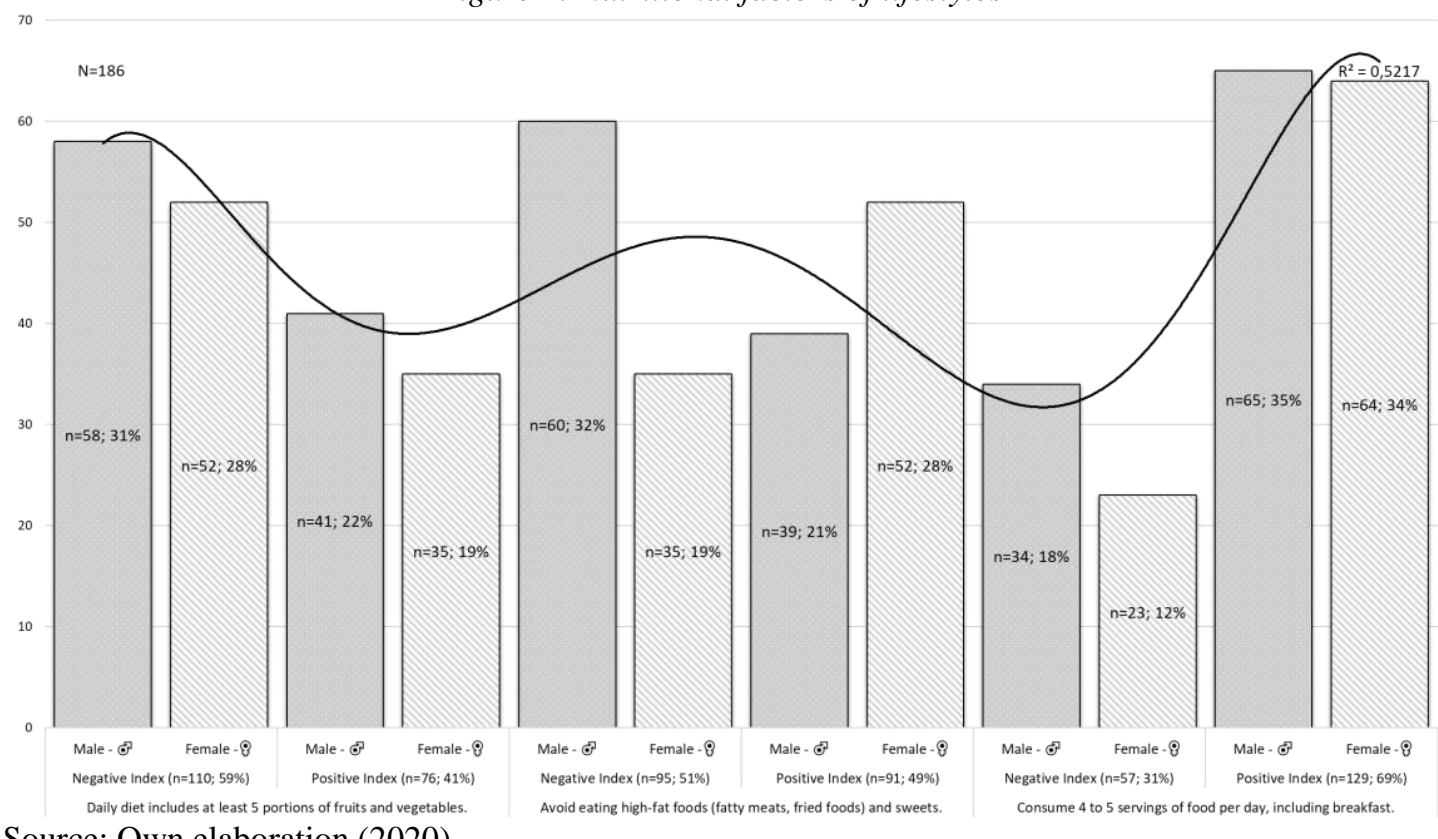

Source: Own elaboration (2020). 


\section{$10^{\text {th }}$ INTERNATIONAL CONFERENCE ON}

MANAGEMENT , ECONOMICS AND HUMANITIES

\subsection{Physical Activity}

For the sample contemplated in this research, $56 \%(n=105)$ do not perform at least 30 minutes of moderate or intense physical activity continuously or cumulatively 5 or more days a week, while $44 \%(n=81)$ do; on the other hand, 55\% $(n=103)$ do not do at least twice a week exercises involving muscle strength and stretching and $45 \%(\mathrm{n}=83)$ do; likewise $56 \%(n=104)$ in their day-to-day, do not walk or use a bicycle as a means of transportation or preferably do not use the stairs instead of the elevator, but $44 \%$ $(n=82)$ do. In that sense, physical activity for postgraduate students is an element that for some is incorporated into their daily activities, but for others, for example, taking actions such as using the elevator or other means of transportation other than the bicycle leads them to exercise less than those who do so frequently. The results show a negative lifestyle index for the dimension of physical activity, and both genders have similar results that in the long term can have several implications for physical health. The following figure presents the most important data.

Figure 2: Physical activity in lifestyles

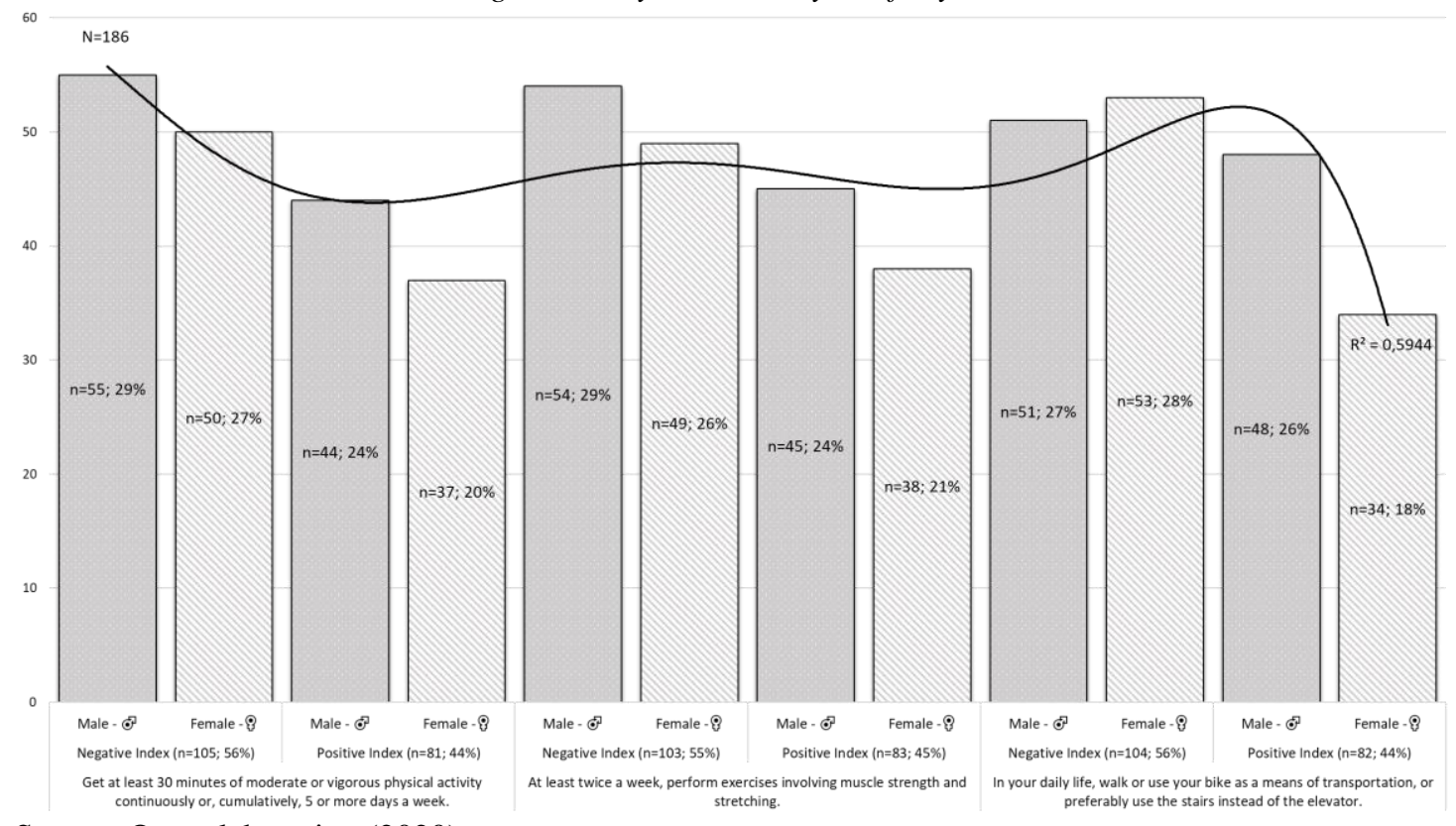

Source: Own elaboration (2020).

\subsection{Preventive behavior}

For this aspect, $64 \%(\mathrm{n}=118)$ of the students consulted do not know their blood pressure, nor their cholesterol levels, only $36 \%(\mathrm{n}=68)$ know them; regarding tobacco or alcohol consumption only $11 \%(n=21)$ smoke and/or consume alcohol in moderation 


\section{$10^{\text {th }}$ INTERNATIONAL CONFERENCE ON}

\section{MANAGEMENT , ECONOMICS AND HUMANITIES}

23-25 October, 2020

Amsterdam,Netherlands

(less than 2 times a day), while $89 \%(n=165)$ do not; On the other hand, regarding behaviors such as the use of seat belts when driving, the respect for traffic rules and never consuming alcohol when driving, 3\% $(n=6)$ do not do so, but 97\% $(n=180)$ do take into account these safety rules and as part of the preventive behavior. The results show a negative rate in a single component of preventive behavior, which in turn, not knowing their current clinical status may be associated with high mortality rates worldwide, since preventive behavior through regular health checks is the best way to prevent, detect early, diagnose or treat a disease. Also, the results show that both genders present the same behavior. The following figure presents the information.

Figure 3: Preventive behavior and lifestyles

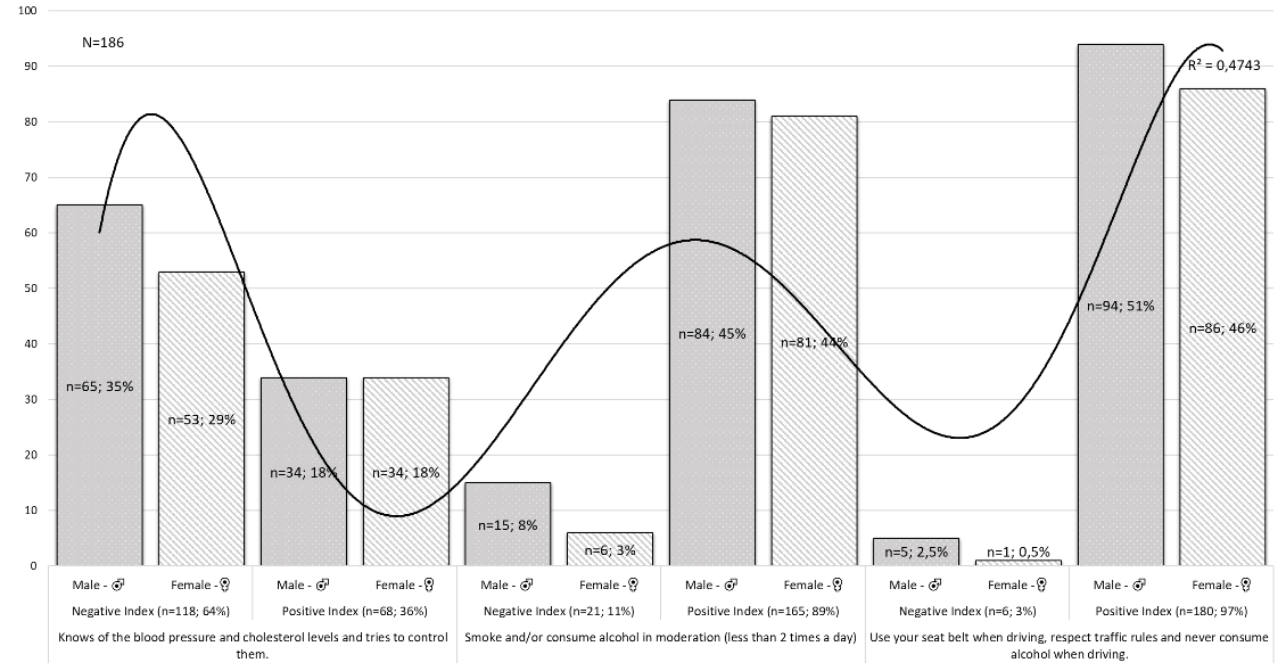

Source: Own elaboration (2020).

\subsection{Social Relations}

On the other hand, 90\% $(n=168)$ of the postgraduate students keep their friends and are satisfied with their friendship, but $10 \%(n=18)$ do not do so; for $62 \%(n=115)$ in their free time they include relationships with friends, group sports activities or participate in social groups, while $38 \%(\mathrm{n}=71)$ do not do so and $54 \%(\mathrm{n}=100)$ actively participate in their community feeling useful in their social environment, but $46 \%$ $(n=86)$ do not participate in this type of activities. The results show a positive lifestyle index in all the evaluated components of social relations. In turn, these results show a 


\section{$10^{\text {th }}$ INTERNATIONAL CONFERENCE ON}

\section{MANAGEMENT , ECONOMICS AND HUMANITIES}

23-25 October, 2020

Amsterdam,Netherlands

stage of life where psychological development is of great interest, and in turn, is immersed in a socio-cultural environment. In accordance with the above, during human development in its different stages, considering the variability and individuality of each person, they establish their own lifestyle, which is intimately related to mental health and their social relationships. In the following figure you can find the figures.

Figure 4: Social relationships and lifestyles

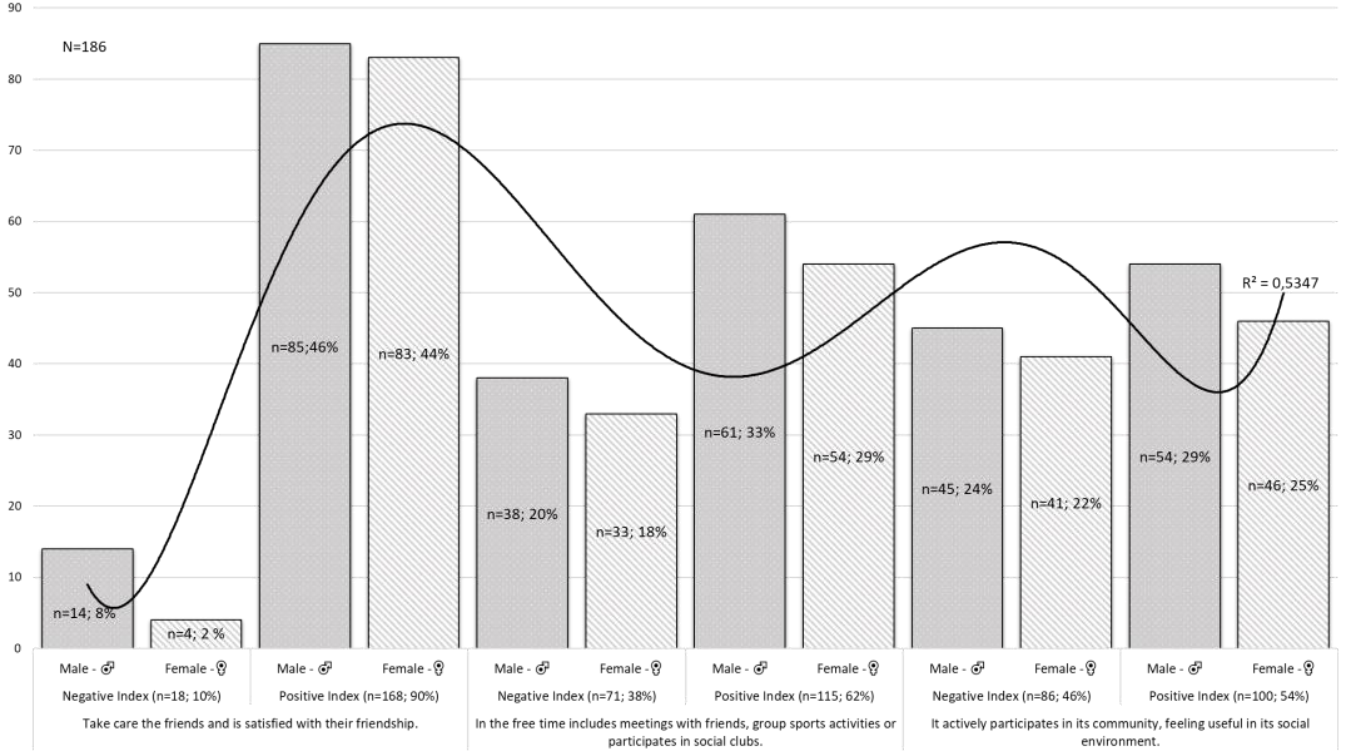

Source: Own elaboration (2020).

\subsection{Stress Management}

Finally, $65 \%(\mathrm{n}=121)$ dedicate time (at least 5 minutes) every day to relax, but $35 \%$ $(n=65)$ do not; for $70 \%(n=129)$ it is possible to have a discussion without getting upset, when they disagree, while for $30 \%(n=57)$ they cannot do it; $73 \%(n=135)$ try to balance time dedicated to study with free time, but for $27 \%(\mathrm{n}=51)$ it is difficult to do so. The results show a positive lifestyle index in all components of stress management. In turn, 
these results show a different trend from the literature since in the university context students face multiple burdens and responsibilities associated with decision making. These academic burdens can impact lifestyle positively or negatively in areas such as physical and mental health, depending on the individual's attitude towards the demands of daily life. The following figure shows the percentages for each item.

Figure 5: Stress Management and Lifestyle

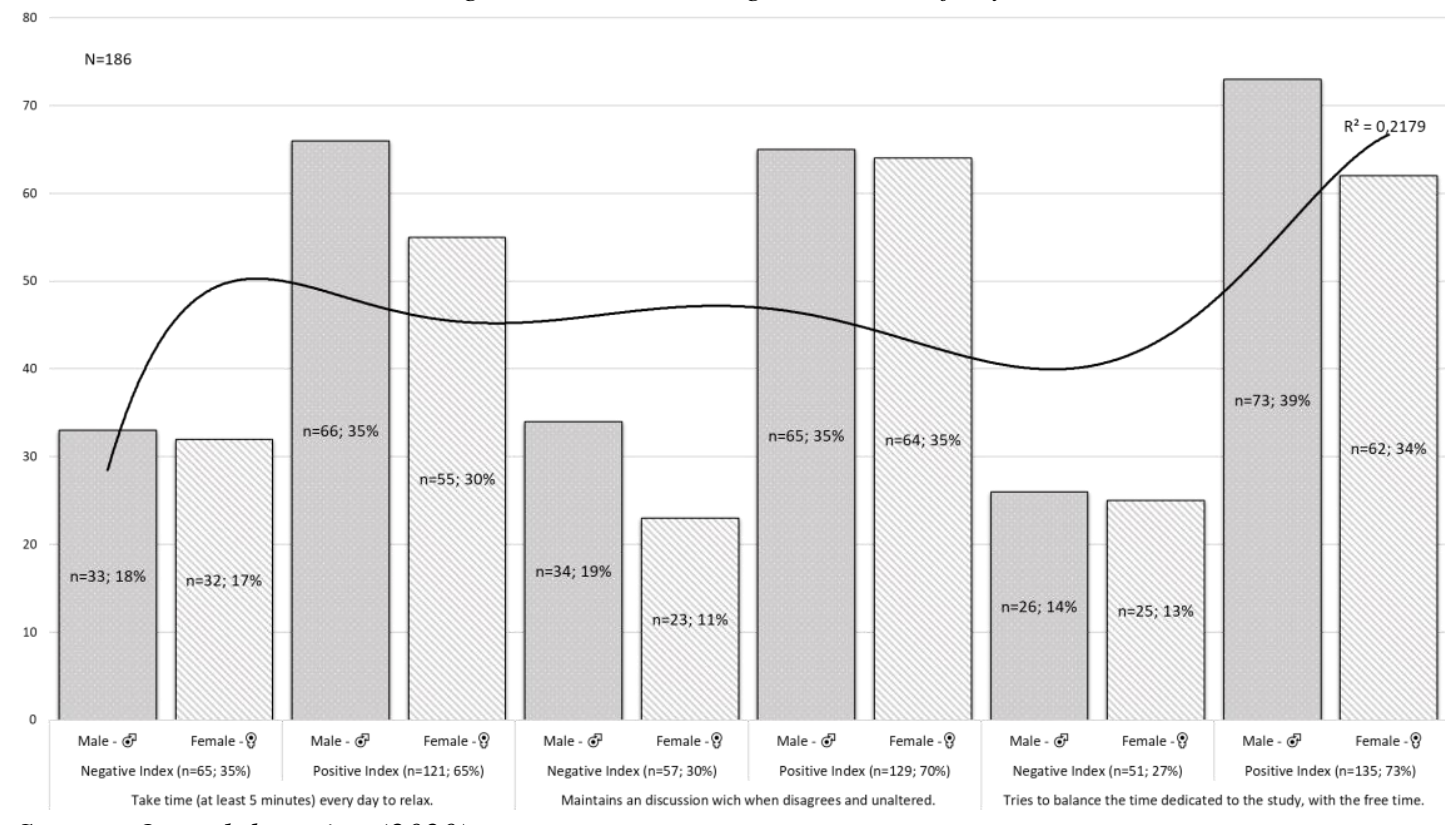

Source: Own elaboration (2020).

Therefore, it is important to mention that postgraduate students present characteristics that interfere with being able to maintain a healthy life, since workload and academic load generate changes in nutritional habits, physical activity, and sleep and rest patterns. In turn, this concern with the lifestyle in the university environment is part of the dimensions of action of welfare in higher education institutions provided for in the policies established by the Ministry of National Education of Colombia (MEN, 2016, p. 28), that the institutions must establish "strategies aimed at promoting healthy habits and encouraging physical activity, sports and adequate use of free time", as well as "strategies related to prevention and promotion of healthy lifestyles and selfcare". 


\section{Conclusion}

The results show a trend of unhealthy lifestyle behavior in postgraduate students, which in the future may lead to a deterioration of health and quality of life and the development of Chronic Noncommunicable Diseases - NCDs. In turn, changes in human behavior are associated with the environment and context in which they live. In this sense, the human lifestyle presents interactions between living conditions and individual behavior patterns that are determined by biopsychosocial characteristics and by the social and cultural context. Therefore, the results show an onset of lifestyle deterioration in postgraduate students, which is related to the stage of adult life where autonomy to make decisions related to leisure and lifestyle reflect the quality of life and well-being in the future.

Considering the current characteristics and demands of society, the new lifestyles have favored the development of unhealthy habits which increase the risk of NCD, such as diabetes, heart, and respiratory diseases. On the other hand, issues such as nutrition, stress, physical activity, preventive behavior, and social relationships are elements that affect people's health and are associated with the development of NCDs mentioned above. From the results of this research, it is evident that more studies on lifestyles and problems associated with them are needed, as a reflection of the quality of life towards the promotion of health of university postgraduate students. Many more studies like these are needed, which will allow universities to design promotion and prevention programs for postgraduate students, who many times due to their work, academic or personal and social activities are not able to do so, and in the university wellness spaces would be an opportune option to favor these reviews.

Finally, it is necessary to provide spaces for the development of a healthy lifestyle through university welfare that offer postgraduate students, health promotion and prevention programs; likewise promote awareness of a healthy lifestyle within the classes offered in postgraduate programs, so that they have a direct impact on the overall formation of students.

\section{Acknowledgment}

This research is part of the FODEIN 2020 call and is funded by the Direction of Research and Innovation of the Universidad Santo Tomás - Bogotá, Colombia. We thank the Department of Humanities and Integral Formation and the postgraduate students of the class of Humanism, Society and Ethics, for their participation in this research.

\section{References}

ACSM. (2018). ACSM's Guidelines for Exercise Testing and Prescription. Philadelphia: Lipincott Williams \& Wilkins.

Arestedt, L. et al. (2014). Living as a family in the midst of chronic illness. Scand J Caring Sci, 28(1), pp. 29-37.

Arrivillaga, M. et al. (2003). Creencias sobre la salud y su relación con las prácticas de riesgo o de protección en jóvenes universitarios. Colombia Médica, 34(4), pp. 186-95. 
Asociación Nacional de Universidades e Instituciones de Educación Superior - ANUIES. (2000). La educación superior en el siglo XXI. Recuperado de: http://planeacion.uaemex.mx/InfBasCon/LaEducacionSuperiorenelSigloXXI.pdf.

Baessler, J. y Schwarcer, R. (1996). Evaluación de la autoeficacia: Adaptación española de la escala de Autoeficacia General. Ansiedad y Estrés, 2, pp.1-8.

Brinkman, D. J., Tichelaar, J., Schutte, T., Benemei, S., Böttiger, Y., Chamontin, B., \& Monteiro, E. C. (2017). Essential competencies in prescribing: A first European crosssectional study among 895 final year medical students. Clinical Pharmacology \& Therapeutics. 101 (2): pp. 281-289.

Centers for Disease Control and Prevention (2018). Strategies to Improve the Quality of Physical Education. USA: Department of Health and Human Services.

Chalela, S., Valencia, A., Arango, D. y Botero, D. (2017). Motivaciones de los estudiantes universitarios para continuar con su formación académica en programas de posgrado. En: Revista Lasallista de Investigación. 14 (2), pp. 160 - 170. DOI: 10.22507/rli. v14n2a15.

Colonia, S. (2010). Caracterización del perfil de los estudiantes de posgrado a partir de la información de admisión y el desempeño académico. http://bdigital.unal.edu.co/3601/1/42144324.2010.pdf.

Consejo Nacional de Acreditación - CNA. (2006). Lineamientos para la acreditación institucional. Bogotá: Corcas Editores LTDA.

Cotrina, J., Rodríguez, J. (2014). Estilo de Vida y factores Biopsicoculturales del Adulto Joven H.U. Lomas Del Sur - Nuevo Chimbote. In Cres., 5(1), pp. 13-22.

De Souza Martins, M. et al. (2015). Analysis of the Lifestyle of Students of Pontificia Javeriana University Colombia. Medicine \& Science in Sports \& Exercise, 47(5), pp. 915.

De Souza Martins, M. et al. (2017). Estilo de vida y factores socioeconómicos en estudiantes de electivas de actividad física y deporte de la Pontificia Universidad Javeriana. Análisis, 49(90), pp. 229-243.

Departamento de Humanidades y Formación Integral - DHFI. (2015). Documento Marco Humanidades. Bogotá: Ediciones USTA.

Diez, O. y López, R. (2017). Estudiantes universitarios y el estilo de vida. Revista Iberoamericana de Producción Académica y Gestión Educativa, 4(8), pp. 1-15.

Espinoza, M. y González, G. (2014). Estudiantes de posgrado: una muestra de perseverancia académica. Revista Interamericana de Ciencias. http://www.reibci.org/publicados/2014/mayo/4568469.pdf.

Gómez-Acosta, C. (2018). Factores psicológicos predictores de estilos de vida saludable. Revista de Salud Pública, 20(2), pp. 155-162.

Grau, J. (2016). Enfermedades crónicas no trasmisibles un abordaje desde los factores psicosociales. Salud \& Sociedad, 7(2), pp. 138-166.

Hernández Sampieri, R., Fernández Collado, C., Baptista Lucio, P. (2018). Metodología de la investigación. México D.F.: McGraw-Hill.

Jaramillo, M. (2015). Estudio comparativo de tendencias de los posgrados en Colombia. Medellín: Red Colombiana de Posgrados.

Krupp, M., Chatton, M. (2014). Current medical diagnosis \& treatment. Los Altos: Lange Medical.

Luna, A.B. (2017). Indicadores de excelencia académica, la perspectiva de estudiantes de posgrado. Journal for Educators, Teachers and Trainers, Vol. 8(1). pp. 61 - 73. 
Marín-Cano, M.L. y Palacio-Bernal, J.C. (2017). Caracterización del desarrollo profesional de estudiantes de un programa de maestría en educación. Un estudio de caso. Revista Latinoamericana de Estudios Educativos, 13 (1), pp. 47-64. DOI: 10.17151/rlee.2017.13.1.3.

MEN (2016). Lineamientos de Política de Bienestar para Instituciones de Educación Superior. Bogotá, Colombia: MEN.

$\begin{array}{lllll}\text { Ministerio de } & \text { (2019), Decreto } & \text { Deciónal }\end{array}$ https://www.mineducacion.gov.co/1759/articles-387348_archivo_pdf.pdf.

Muchotrigo, M. (2012). Estilo de vida saludable en estudiantes de posgrado de Ciencias de la Salud. Psicología y Salud, 22 (1), pp. 75-87.

Nahas, M. (2013). Atividade física, saúde e qualidade de vida: conceitos e sugestões para um estilo de vida ativo. Londrina: Midiograf.

Nusbaum, M. (2010). Sin fines de lucro. Por qué la democracia necesita de las humanidades. Madrid: Katz Editores.

OMS (2013). Action Plan for the Global Strategy for the Prevention and Control of Noncommunicable Diseases. Ginebra: WHO.

Organización de las Naciones Unidas para la Educación la Ciencia y la Cultura - UNESCO. (2009). Conferencia Mundial sobre la Educación Superior. La nueva dinámica de la educación superior y la investigación para el cambio social y el desarrollo. http://www.unesco.org/education/WCHE2009/comunicado_es.pdf.

Sanabria, P. et al. (2007). Estilos de vida saludables en profesionales de la salud colombianos. Estudio exploratorio. Revista Med, 5(2), pp. 207-17.

Shelton, L. (2019). The Bronfenbrenner Primer. New York: Routledge.

Suescún-Carrero, S. et al. (2017). Estilos de vida en estudiantes de una universidad de Boyacá, Colombia. Re Fac. Med. 65, pp. 227-231.

Universidad Santo Tomás (2004). Proyecto Educativo Institucional - PEI. Bogotá: Ediciones USTA.

Universidad Santo Tomás (2009). Modelo Pedagógico Institucional. Bogotá: Ediciones USTA.

Universidad Santo Tomás (2010). Estatuto orgánico. Bogotá: Ediciones USTA.

Urrutia-Aguilar, ME., Aburto AM., Arce CA., Guevara-Guzmán R. (2015). La formación docente evaluada por método mixto. Revista Fundación Educación Médica, 18(5): pp. 337-343.

Valdez- Cuervo, A., Vera-Noguera, J., Martínez, E. y Etevez-Nenninger, E. (2013). Perfiles de estudiantes de posgrado en ciencias e ingenierías en sonora. Revista Iberoamericana de Educación Superior. https://reader.elsevier.com/reader/sd/pii/S200728721371922X?token=4C432BA419B B02A251A6E242961D481AEB746D876373FC96A11452931537E7251B41A7BBB 0EF9AB80BA433EC3608B8F6.

Wilches-Luna E.C, Muñoz-Arcos V, Carvajal-Tello N, Segura-Ordóñez A. (2016). Caracterización e impacto percibido de los egresados de un posgrado en Fisioterapia Cardiopulmonar de una universidad pública del suroccidente colombiano. Periodo 2009-2013. Revista Ciencias de la Salud. 14(1): pp. 43-52. DOI: dx.doi.org/10.12804/revsalud14.01.2016.04. 